Biol. Stud. 2018: 12(3-4); 95-102 • DOI: https://doi.org/10.30970/sbi.1203.571

www.http://publications.Inu.edu.ua/journals/index.php/biology

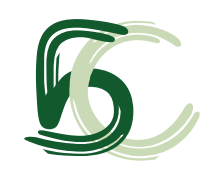

УДК 582.9

CHAMAEDAPHNE CALYCULATA (L.) MOENCH В УKPAÏHI

\author{
С. Л. Жигалова*1, І. Г. Ольшанський', О. А. Футорна² \\ 1/нститут ботаніки ім. М. Г. Холодного НАН України \\ вул. Терещенківська, 1, Київ 01004, Україна \\ Ботанічний сад ім. акад. О. В. Фоміна, ННЦ "Інститут біології та медицини" \\ Київський національний університет імені Тараса Шевченка \\ вул. Симона Петлюри, 1, Київ 01601, Україна \\ *Кореспондуючий автор: *e-mail: zhygalova2015@gmail.com
}

Zhygalova S. L., Olshanskyi I. G., Futorna O. A. Chamaedaphne calyculata (L.) Moench in Ukraine. Studia Biologica, 2018: 12(3-4); 95-102 • DOI: https://doi.org/10.30970/sbi.1203.571

На основі критичного опрацювання численних літературних джерел і матеріалів гербаріїв узагальнено відомості про систематичне положення, морфологічну будову, екологічну приуроченість, географрічне поширення та стан охорони Chamaedaphne calyculata (L.) Moench. Chamaedaphne calyculata належить до монотипного роду Chamaedaphne з родини вересових (Ericaceae). Chamaedaphne calyculata - болотний і лісоболотний вид рослин. В Україні він $є$ гляціальним (плейстоценовим) реліктом на південній межі поширення, занесений до Червоної книги України (2009), має статус “вразливий”. Угруповання, в яких домінує C. calyculata, включені до Зеленої книги України (2009). Chamaedaphne calyculata має лікарські властивості, а також декоративне, ґрунтозахисне, торфофрормуюче значення. Цей вид рослин поширений у сусідніх з Україною країнах: у Польщі, Білорусі, Росії. Причому вже на півдні Білорусі він трапляється спорадично, а в Польщі належить до рідкісних видів рослин. В Україні наявні лише кілька локалітетів C. calyculata. За допомогою ресурсу SimpleMappr нами створена карта поширення цього виду. З'ясовано, що C. calyculata охороняється в кількох об'єктах природно-заповідного фонду України: Рівненський і Поліський природні заповідники, Вутвицький, Сварицевицький та Хиноцький ботанічні заказники загальнодержавного значення. За результатами аналізу літературних даних ми дійшли висновку, що цей вид потребує дослідження сучасного стану популяцій. Оскільки більшість гербарних зразків C. calyculata зібрані у 50-70-х роках минулого століття, ці місцезнаходження потребують підтвердження. Також необхідний пошук нових місцезростань цього виду рослин. Підкреслюємо, що, зважаючи на те, що не

(C) 2018 S. L. Zhygalova et al.; Published by the Ivan Franko National University of Lviv on behalf of Біологічні Студії / Studia Biologica. This is an Open Access article distributed under the terms of the Creative Commons Attribution License (http://www.budapestopenaccessinitiative.org/ and Creative Commons Attribution 4.0 License), which permits unrestricted reuse, distribution, and reproduction in any medium, provided the original work is properly cited.

ISSN 1996-4536 (print) • ISSN 2311-0783 (on-line) • Біологічні Студії / Studia Biologica • 2018 • Том 12/№3-4 • C. 95-102 
всі осередки C. calyculata перебувають під охороною, необхідне створення нових об'єктів природно-заповідного фонду України або розширення наявних.

Ключові слова: Ericaceae, Chamaedaphne, Червона книга України

\section{ВСТУП}

Chamaedaphne calyculata (L.) Moench - болотний і лісоболотний вид рослин, рідкісний для України [2, 5]. Назва "хамедафна" походить з грецької мови (від chamai - на землі, та daphne - лавр [11]), тобто означає “приземкуватий лавр”, “низенький лавр”. Справді, шкірясті листки хамедафни подібні до листків лавра, лише дрібніші, і сама рослина набагато нижча [3]. Як показали дослідження захоронень вікінгів [24], хамедафна використовувалася племенами, які жили на території сучасної Скандинавії, для виготовлення алкогольного напою - “нордичного грогу”. Рослини містять у листках і молодих пагонах глікозид андромедотоксин, що може викликати отруєння людей і тварин [14]. Андромедотоксин належить до нейротоксинів, його токсичність обумовлена тим, що він порушує роботу нервових рецепторів: спочатку збуджує центральну нервову систему, а потім її пригнічує, що може призвести до летального результату [15]. Згідно зі сучасними дослідженнями, C. calyculata має й лікарські властивості: болезаспокійливі, антисептичні, протисудомні (у разі епілепсії) - завдяки вмісту дитерпеноїдів, френолкарбонових кислот, фрлавоноїдів [25]. Також C. calyculata має декоративне, ґрунтозахисне, торфоформуюче значення [2].

Метою нашої роботи було узагальнити наявні відомості про систематику, морфологічну будову, екологічну приуроченість C. calyculata, уточнити географрічне поширення цього рідкісного виду в Україні, а також дані про заходи з охорони та збереження популяцій.

\section{МАТЕРІАЛИ ТА МЕТОДИ ДОСЛІДЖЕНЬ}

Робота ґрунтується на результатах критичного опрацювання численних літературних джерел та матеріалів гербаріїв. Акроніми останніх подано за обробкою Н.М. Шиян "Гербарії України” [31]: KW - Національний гербарій України - гербарій Інституту ботаніки ім. М.Г. Холодного НАН України; $R N R^{*}-$ Гербарій Рівненського природного заповідника (не зареєстрований у міжнародній базі Index Herbariorum).

Назви таксонів подано за зведенням С.Л. Мосякіна та М.М. Федорончука [27], а назви синтаксонів - L. Mucina, H. Bültmann, K. Dierßen [28].

Карта поширення створена за допомогою SimpleMappr [32].

\section{РЕЗУЛЬТАТИ ДОСЛІДЖЕНЬ І ЇХНЄ ОБГОВОРЕННЯ}

Номенклатура й таксономія. Chamaedaphne calyculata - єдиний вид у роді Chamaedaphne родини вересових (Ericaceae).

Chamaedaphne calyculata (L.) Moench, 1794, Meth. PI.: 457; Буш, 1952, Фл. CССР, 18: 76; Барбарич, 1957, Фл. УРСР, 8: 47; Webb, 1972, FI. Europ. 3: 12; Виноградова, 1981, Фл. европ. ч. СССР, 5: 47. - хамедафна чашкова, хамедафна чашечкова, торф'яниця чашечкова (англ. - leatherleaf, польськ. - chamedafne pyinocna, рос. - хамедафне прицветничковая, болотный мирт чашечный, кит. - 属有).

三Andromeda calyculata L. 1753, Sp. PI.: 394.

ELyonia calyculata (L.) Rchh. 1831, FI. Germ. Excurs. 1: 414.

ISSN 1996-4536 (print) • ISSN 2311-0783 (on-line) • Біологічні Студії / Studia Biologica • 2018 • Том 12/№3-4 • С. 95-102 
三Cassandra calyculata (L.) D.Don. 1834. Edinb. N. Phil. Journ. 17(33): 158; Шмальгаузен, 1887, Флора Средней и Южной России, Крыма и Северного Кавказа, 2: 184. Sibiria”.

Вид описаний з Вірджинії [США], Канади та Сибіру [РФ]: “in Virginia, Canada,

Лектотип (LINN): Herb. Linn. 563.17, правий зразок на гербарному аркуші [10; http://plants.jstor.org/stable/10.5555/al.ap.specimen.linn-hl563-17].

$2 n=22[22,26]$.

Морфологічна будова. Вічнозелений (за іншими даними - напівлистопадний [18]) кущик 20-60 (80) см заввишки, з розгалуженим прямостоячим стеблом. Молоді пагони вкриті зонтикоподібними лусочками й опушені. Кора сірувато-бура. Листки 1-5 см завдовжки й до 1,5 см завширшки, чергові, шкірясті, вузькоеліптичні або вузько-оберненояйцеподібні, з трохи загостреною, тупою або заокругленою верхівкою, майже сидячі, по злегка загорнутому краю неясно городчасті або майже цілокраї, на обох поверхнях вкриті округлими лусочками, зверху сірувато-зелені, зісподу світліші, з виступаючою головною жилкою. На обох поверхнях листків наявні округлі лусочки, які є складними розгалуженими волосками (squamiformes), розміщеними в одній площині, та мають галуження неоднакової довжини (зрідка однакової) та зростаються між собою, утворюючи пласку лусочку різної форми [13]. Суцвіття - однобічні пониклі китиці, квітки сидять у пазухах листкоподібних приквітків, які поступово зменшуються до верхівки. Чашечки майже удвічі коротші від віночка, знизу прикриті двома лускоподібними приквітками, їхні частки трикутно-яйцеподібні, загострені, ззовні густо вкриті лусочками, по краю війчасті. Чашолистки до 3 мм завдовжки та 1,5 мм завширшки. Віночок дзвоникуватий або видовжено-яйцеподібний, жовтувато-білий, 6-7 мм завдовжки, на третину розділений на притуплені трикутні частки. Тичинок 10, пиляки дворогі. Пилкові зерна зібрані в тетради діаметром 30,6-32,6 мкм, трикольпоратні, сплющені, полярна вісь 15,9-16,6 мкм, екваторіальний діаметр 22,8-23,0 мкм [30]. Стовпчик маточки циліндричний, трохи виступає з віночка. Плід - багатонасінна стиснуто-куляста коробочка, 2-3 мм завдовжки. Насінини жовтогарячі, до 1,0 мм завдовжки, яйцеподібні, плескаті [6, 7, 22].

Біологічні особливості. На відкритих місцях C. calyculata часто фрормує густі чагарникові зарості, на екотоні між лісом і торфовищем може формувати чагарникові смуги, у заболочених борах росте поодинокими особинами. На відкритих місцевостях - квітує і плодоносить. В Україні квітує наприкінці травня - у червні. Розмножується насінням і розростанням куртин [3, 4].

На території Польщі розмножується, головно, вегетативно, хоча може й насінням [21]. У північних регіонах Землі насіння хамедафни споживають білі куріпки [21], тому можлива й зоохорія.

В онтогенезі C. calyculata М. Мазуренко виділила чотири періоди: 1) проростання та розвиток первинного пагона - 1-4 роки; 2) кущіння - 4-15 років; 3) фоормування скелетних осей, початок квітування - 10-30 років; 4) розвиток вегетативно рухомих парціальних кущів, клонування - 30 років і більше [23].

Ареал. Вид диз'юнктивно поширений у Північній Америці, у субарктичній і бореальній зонах Євразії (на південь до $52^{\circ}$ пн.д.) до південно-східного Китаю та північної Японії. Зокрема, C. calyculata росте на сусідніх з Україною територіях: у Польщі, Білорусі, Росії. Причому вже на півдні Білорусі він трапляється спорадично, а в Польщі належить до рідкісних видів рослин [3, 5, 6, 35].

ISSN 1996-4536 (print) • ISSN 2311-0783 (on-line) • Біологічні Студії / Studia Biologica • 2018 • Том 12/№3-4 • С. 95-102 
Поширення в Україні. В Україні наявні лише декілька локалітетів C. calyculata (див. рисунок):

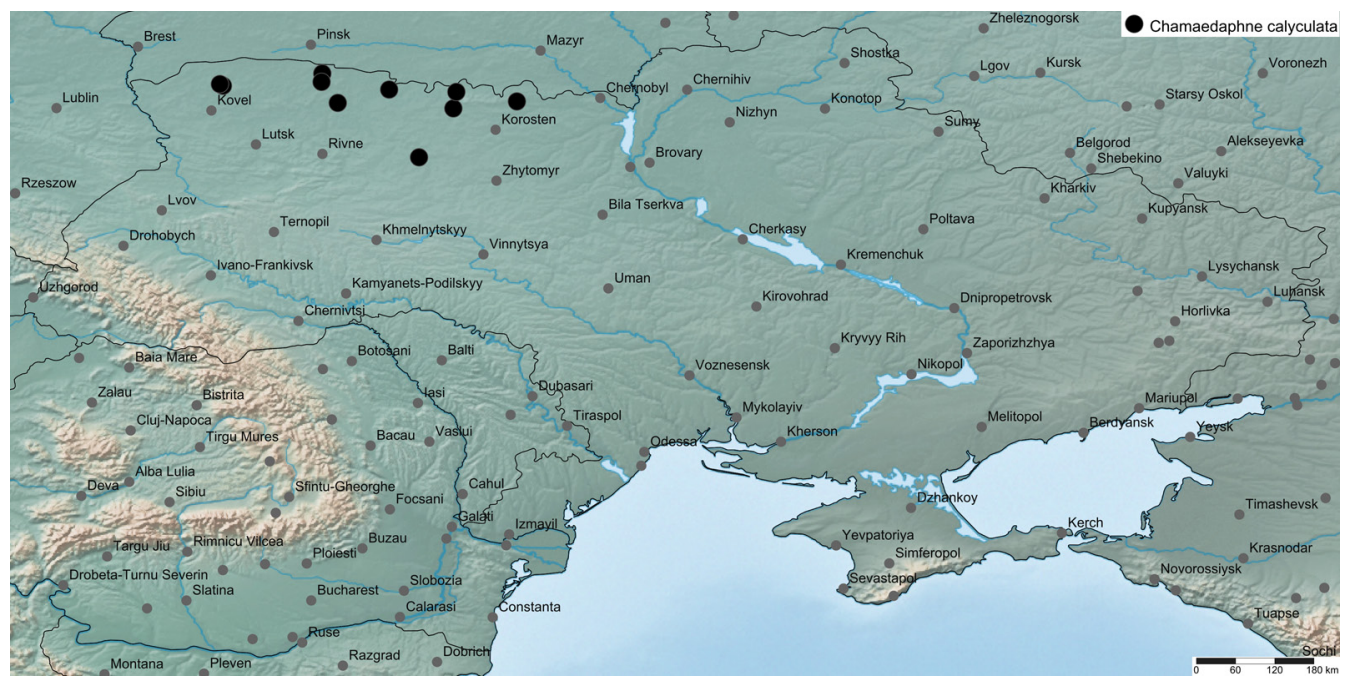

Поширення Chamaedaphne calyculata в Україні

The distribution of Chamaedaphne calyculata in Ukraine

Волинська обл.: Камінь-Каширський р-н, с. Підріччя. Підріччянська лісова дача. Між озерами Мачулиним і Добрим, к сфрагновому сосняку. 15.08. 1962. Ю.С. Шевченко, М.Т. Слободян (КW!); Камінь-Каширський р-н, околиці с. Нуйно, у сорагновому сосняку IV бонітету, на болоті між озерами Добре та Мачулине [34]; Камінь-Каширський р-н, Нуйнівське лісництво, болото Гале. 11.08.1971. Т.Л. Андрієнко, О.І. Прядко (КW!); Камінь-Каширський р-н, Нуйнівське лісництво, болото Вутвицьке, 12.08.1971. Т.Л. Андрієнко, О.І. Прядко (КW!).

Рівненська обл.: Ракитновский р-н, олиготрофное болото Сырая Погоня между с.с. Вежица и Ельно. 30.07.1951. Е.М. Брадис (КW!); Дубровицкий р-н, Сварицевичское л-во, урочище Смотрич, болотный массив “Морочно II". 15.07.1976. Т.Л. Андриенко (KW!); Сарненський р-н, с. Чемерне, болото Чемерне. --.--.1975. Т.Л. Андрієнко, RNR* [37]; Володимирецький р-н, Морочно II, сосново-хамедафново-сфрагнова ділянка. --.07.1977. Т.Л. Андрієнко, $R N R^{*}$ [37]; околиці м. Сарни, болото Чемерне [6, 20]; Володимирецький р-н, околиці с. Хиночі, Хиноцьке болото [20].

Житомирська обл.: Коростенщина. Район оз. Корма. Коло с. Озеряни. Озерянське болото (Шевцова Нива), сфрагн. частина. 21.08.1930. Д. Зеров (KW!); Олевський р-н, сфагнове Озерянське болото. 20.06.1930. Д.К. Зеров (KW!); Олевский р-н, болото Озерянское, ур. Шевцова Нива, олиготрофный сосново-кустарничковосфрагновый участок. 31.07.1957. Е. Брадис (KW!); Овруцький р-н, с. Гладковичі; окол. Новоград-Волинського [1]. Найсхідніше з відомих в Україні місцезнаходження: Овруцький р-н, ДП “Словечанське ЛГ”, Сирницьке лісництво, квартал 73, на краю олігомезотрофного болота, у заболоченому березово-сосновому лісі, охоронна зона Селезівського лісництва Поліського ПЗ [3, 6, 9]

Вказівку для околиць Черкас [16] ми вважаємо помилковою.

Умови місцезростань. Chamaedaphne calyculata росте в угрупованнях класів Scheuchzerio palustris-Caricetea fuscae Tx. 1937, Oxycocco-Sphagnetea Br.-BI. et

ISSN 1996-4536 (print) • ISSN 2311-0783 (on-line) • Біологічні Студії / Studia Biologica • 2018 • Том 12/№3-4 • С. 95-102 
Tx. ex Westhoff et al. 1946 та Vaccinio-Piceetea Br.-BI. in Br.-BI. et al. 1939 [2, 20]. 3oкрема, за даними Т.Л. Андрієнко, C. calyculata найчастіше трапляється на лісових і рідколісних, досить обводнених оліготрофних та мезотрофрних болотах із розрідженою сосною [2]. Згідно з дослідженнями В.В. Коніщука [20], цей вид рослин поширений на верхових і перехідних бореальних болотах із малопотужними (до 3 м, в окремих випадках більше) торфовими покладами, близьким до денної поверхні заляганням суглинистих, карбонатних порід. Угруповання за участю C. calyculata маловидові, налічують до 10 видів $[2,20]$. На території сусідньої Польщі C. calyculata трапляється на верхових болотах, на сильно зволожених кислих ґрунтах (з рН<5), частіше - на відкритих місцях, зрідка - в затіненні [21].

Чисельність і структура популяцій. Популяції нечисленні, найбільші - площею 0,5-1 га, щільні [2].

Причини зміни чисельності популяцій: осушення та освоєння боліт і прилеглих територій. Чутливість до екологічних змін на південній межі поширення [2]. Разом з тим, $є$ дані, що C. calyculata $€$ одним із видів, які позитивно реагують на підсушення території через загальне зниження рівня ґрунтових вод [17].

Охорона. В Україні вид є гляціальним (плейстоценовим) реліктом на південній межі поширення. Він занесений до Червоної книги України [2], має статус "вразливий". А угруповання, в яких домінує C. calyculata, включені до Зеленої книги України [12].

Chamaedaphne calyculata охороняється в кількох об'єктах природно-заповідного фонду України:

Волинська обл.: Вутвицький ботанічний заказник загальнодержавного значення (Камінь-Каширський р-н, на захід від с. Нуйно) [1, 2];

Рівненська обл.: Рівненський природний заповідник - ділянки Сира Погоня (місцезростання виявлене Є.М. Брадіс на початку 50-х років [8], наразі не підтверджене) та Білоозерська [2]; Сварицевицький ботанічний заказник загальнодержавного значення (Дубровицький р-н, на північ від с. Сварицевичі) [1, 2]; Хиноцький ботанічний заказник загальнодержавного значення (Володимирецький р-н, на північ від с. Хиночі).

Заходи охорони: організація ботанічних заказників, розробка способів розмноження в культурі, контроль за станом популяцій, виявлення нових локалітетів. Заборонено збирання та заготівлю рослин, порушення умов місцезростання, особливо проведення меліоративних робіт [2].

$€$ відомості про успішну репатріацію $C$. calyculata в Польщі, проведену ще німецькими ботаніками [21]. А також, за даними J. Kruszelnicki, C. calyculata у сприятливих умовах може досить швидко розмножуватися вегетативно - із посаджених двох кущів за 30 років їхня чисельність зросла до 90 [21]. Також у Польщі проводились експерименти з вирощування C. calyculata in vitro, в результаті чого в 2009 р. у природу було висаджено шість рослин, вирощених у такий спосіб [38].

На території України C. calyculata культивується у Ботанічному саду ім. акад. О.В. Фоміна Київського національного університету імені Тараса Шевченка [19].

Загалом, хамедафна чашечкова охороняється в Україні [2] та Польщі [21], а також на регіональному рівні в Житомирській області України та в багатьох регіонах РФ: в Алтайському краї, Республіці Башкортостан, Республіці Татарстан, Чуваській республіці, Брянській, Калінінградській, Калузькій, Липецькій, Мурманській, Пензенській, Тамбовській, Тульській і Ульянівській областях, а також у Москві (за даними сайту www.plantarium.ru).

ISSN 1996-4536 (print) • ISSN 2311-0783 (on-line) • Біологічні Студії / Studia Biologica • 2018 • Том 12/№3-4 • С. 95-102 


\section{висновки}

Зібрано і проаналізовано наявні відомості про систематику, морфологічну будову, екологічну приуроченість C. calyculata, уточнено географічне поширення цього рідкісного виду в Україні, а також досвід заходів з охорони та збереження популяцій. Аналіз літературних даних дав підстави зробити висновок, що цей вид потребує дослідження сучасного стану популяцій. Більшість гербарних зразків C. calyculata зібрані у 50-70-х роках минулого століття, тому ці місцезнаходження потребують підтвердження. Також необхідний пошук нових місцезростань цього виду рослин. Зважаючи на те, що не всі місцезростання C. calyculata перебувають під охороною, необхідне створення нових об'єктів природно-заповідного фронду України або розширення наявних.

1. Andrienko T.L. (Ed.), Onyshchenko V.A., Pryadko O.I., Panchenko S.M., Arap R.Ya., Konishchuk V.V., Lukash O.V., Karpenko Yu.O., Virchenko V.M., Chornous O.P. Phytodiversity of the Ukrainian Polissia and its conservation. Kyiv: Phytosociocenter, 2006. 316 p. (In Ukrainian).

2. Andrienko T.L. Leatherleaf - Chamaedaphne calyculata (L.) Moench. In: Didukh Ya.P. (Ed.) Red Data Book of Ukraine. Kyiv: Globalconsulting, 2009. P.427. (In Ukrainian).

3. Andrienko T.L. Rare boreal species at the plain of Ukraine. Kyiv: Phytosociocenter, 2010. 104 p. (In Ukrainian).

4. Andrienko T.L., Pryadko O.I. Peculiar swamp of Western Polissya with abundant leatherleaf (Chamaedaphne calyculata (L.) Moench). Ukr. Botan. Journ, 1972; 29(1): 117-119. (In Ukrainian).

5. Andrienko T.L., Vynajev G.V. The distribution and ecological-phytocoenic features of Chamaedaphne calyculata (L.) Moench. at the Pripyat Polissya. Ukr. Botan. Journ, 1978; 35(4): 367-370. (In Ukrainian).

6. Barbarych A.I. Chamaedaphne. In: Kotov M.I. (Ed.) The flora of USSR. Vol. 8. Kyiv: Academy of Sciences of the Ukrainian SSR, 1957. P. 47-49. (In Ukrainian).

7. Barbarych A.I. Leatherleaf - Chamaedaphne Moench. In: Prokudin Yu.N., Dobrochayeva D.N., Zaverukha B.V., Chopyk V.I., Protopopova V.V., Kritskaya L.I. (Eds.). The determinant of higher plants of Ukraine, $1^{\text {st }}$ ed. Kyiv: Nauk. Dumka, 1987. P. 135-136. (In Russian).

8. Bradys Ye.M., Bachuryna G.F. Marshes of the Ukrainian SSR. Kyiv: Nauk. Dumka, 1969. 241 p. (In Ukrainian).

9. Bumar H.J. Chamaedaphne calyculata (L.) Moench. in Zhytomyr Polissya. Ukr. Botan. Journ, 1990; 47(4): 73-74. (In Ukrainian).

10. Cafferty S., Jarvis C.E. Typification of Linnaean plant names in Ericaceae. Taxon, 2002b; 51: 751-753.

[DOI: https://doi.org/10.2307/1555030]

11. Chopyk V.I. Rare and endangered plants of Ukraine. Kyiv: Nauk. Dumka, 1978. 212 p. (In Russian).

12. Didukh Ya.P. (Ed.) Green book of Ukraine. Kyiv: Alterpress, 2009. 448 p. (In Ukrainian).

13. Fedorov Al.L., Kirpichnikov M.E., Artyushenko Z.T. Atlas on the descriptive morphology of higher plants. Leaf. Moskow; Leningrad: Izd-vo AN SSSR, 1956. 305 p. (In Russian).

14. Gubanov I.A., Kiselyova K.V., Novikov V.S., Tikhomyrov V.N. Illustrated determinant of plants of Central Russia. Moskow: Obshchestvo Nauchnyh Publikacij KMK, Institut Technologycheskih Nauk, 2004; Vol. 3: 21. (In Russian).

15. Gusynin I.A. Toxicology of poisonous plants, $4^{\text {th }}$ ed. Moskow: Izd-vo selskohoz. lit., zhurnalov i plakatov (Selkhozizdat), 1962. 624 p. (In Russian).

16. Janata O., Janata N. List of plants collected by Dr. Gromega in Cherkassy county in the Kyiv region. Annals of the Natural and Technical Section of the Ukrainian Scientific Society in Kyiv, 1912; 2: 109-154. (In Ukrainian). 
17. Kapustin D., Tsarenko P., Partyka L.Ya., Virchenko V., Orlov O.O. (Ed.), Jupille O., Popovych S.Yu., Bumar H.J. Phytodiversity of Polisky Nature Reserve: Algea, Bryophytes and Vascular Plants. Kyiv: Vyd-vo TOV "NVP "Interservis"”, 2013. 256 p. (In Ukrainian)

18. Khokhryakov A.P., Mazurenko M.T. Leatherleaf - Chamaedaphne Moench. In: Khar kevich S.S. Plantae Vasculares Orientis Extremi Sovetici, Vol. 5. Petropolis: Nauka, 1991. 143-144. (In Russian).

19. Kolisnichenko O.M., Bonyuk Z.G., Grevtsova G.T. (Ed.), Zarubenko A.U., Ivanova I.Ju., Palagecha R.M., Tkachuk O.O. The introduction of tree plants in the Botanical Garden named acad. O.V. Fomin (1839-2009). Kyiv: VPC "Kyivskyi Universitet", 2011. 175 p. (In Ukrainian).

20. Konishchuk V.V. Prodromus of syntaxones Oxycocco palustris - Sphagnetea magellanici phytostromes of peat swamps. Nature of Western Polissya and surrounding areas. Section II. Biology, 2014: 177-182. (In Ukrainian).

21. Kruszelnicki J. Chamaedaphne calyculata (L.) Moench. In: Polska czerwona księga roślin. Kraków: Skleniarz, 2014. 377-379.

22. Malyshev L.I. Chamaedaphne Moench - Leatherleaf. In: Malyshev L.I. (Ed.) Flora of Siberia, Vol. 11. Pyrolaceae - Lamiaceae (Labiatae). Novosibirsk: Nauka. Sybirskaya izdatelskaya firma RAN, 1997. P. 22. (In Russian).

23. Mazurenko M.T. Leatherleaf, Cassandra. In: Khokhryakov A.P. (Ed.) Terrestrial shrubs of the Far East (structure and morphogenesis). Moskow: Nauka, 1982. 94-97. (In Russian).

24. McGovern P.E., Hall G.R., Mirzoian A.A. Biomolecular archaeological approach to 'Nordic grog. Danish Journal of Archaeology, 2013; 2: 112-131.

[DOI: https://doi.org/10.1080/21662282.2013.867101]

25. Minarchenko V.M. Medicinal vascular plants of Ukraine (medical and resource value). Kyiv: Phytosociocenter, 2005. 324 p. (In Ukrainian).

26. Moore D.M. Flora Europaea check-list and chromosome index. New York: Cambridge University Press, 1982. 423 p.

27. Mosyakin S.L., Fedoronchuk M.M. Vascular plants of Ukraine. A nomenclatural checklist. Kiev: M.G. Kholodny Institute of Botany, 1999. 346 p.

28. Mucina L., Bültmann H., Dierßen K., Theurillat J.P., Raus T., Čarni A., Šumberová K., Willner W., Dengler J., Garcha R.G., Chytrý M., Hájek M., Di Pietro R., lakushenko D., Pallas J., Daniëls F.J.A., Bergmeier E., Santos Guerra A., Ermakov N., Valachović M., Schaminée J.H.J., Lysenko T., Didukh Y.P., Pignatti S., Rodwell J.S., Capelo J., Weber H.E., Solomeshch A., Dimopoulos P., Aguiar C., Hennekens S.M., Tichý L., Peet R. Vegetation of Europe: hierarchical floristic classification system of vascular plant, bryophyte, lichen, and algal communites. Applied Vegetation Science, 2016; 19: 3-264.

[DOI: https://doi.org/10.1111/avsc.12257]

29. Pavek Diane S. Chamaedaphne calyculata. In: Fire Effects Information System, [Online]. U.S. Department of Agriculture, Forest Service, Rocky Mountain Research Station, Fire Sciences Laboratory (Producer). 1993. Available: https://www.fs.fed.us/database/feis/plants/ shrub/chacal/all.html [2018, June 22]

30. Sarwar A.K.M. Golam. Pollen Morphology and its Systematic Significance in the Ericaceae. A dissertation submitted in partial fulfillment of the requirements for the degree of Doctor of Philosophy. Hokkaido University, Sapporo, Japan, 2007.302 p. [http://hdl.handle.net/2115/46925]

31. Shiyan N.M. (Ed.) Index Herbariorum Ucrainicum. Kyiv: Alterpres, 2011. 442 p. (In Ukrainian).

32. Shorthouse D.P. SimpleMappr, an online tool to produce publication-quality point maps. 2010. [Retrieved from http://www.simplemappr.net. Accessed September 21, 2018].

33. Shumyk M.I., Ostapjuk V.M. Family Eridaceae DC: ecological and biomorphological aspects of evolution in connection with the introduction of individual representatives. Plant introduction, 2009; 3: 57-62. (In Ukrainian).

34. Slobodyan M.P. Chamaedaphne calyculata (L.) Moench in the west of the Western Polissya. Ukr. Botan. Journ, 1964; 21(1): 98. (In Ukrainian).

35. Webb D.A. Chamaedaphne Moench. In: Tutin T.G., Heywood V.H., Burges N.A., Moore D.M., Valentine D.H., Walters S.M., Webb D.A. (Ed.) Flora Europaea. Vol. 3. London: Cambridge University Press, 1972. P.12.

ISSN 1996-4536 (print) • ISSN 2311-0783 (on-line) • Біологічні Студії / Studia Biologica • 2018 • Том 12/№3-4 • С. 95-102 
36. Wróblewska A. The role of disjunction and postglacial population expansion on phylogeographical history and genetic diversity of the circumboreal plant Chamaedaphne calyculata. Biological Journal of the Linnean Society, 2012; 105: 761-775. [DOI: https://doi.org/10.1111/j.1095-8312.2011.01828.x]

37. Yezhel I.N. Family Ericaceae Juss. in flora of the Right Bank Ukraine Polesye. Phytodiversity of Eastern Europe, 2013; 7(4): 12-70. (In Russian).

38. Źróbek-Sokolnik A., Kucewicz M., Hołdyński C. Zastosowanie kultur in vitro w ochronie Chamaedaphne calyculata (L.) Moench. In: Planta in vivo, in vitro et in silico. LV Zjazd Polskiego Towarzystwa Botanicznego (Warszawa, 6-12 września 2010). Warszawa: ZYX Poligrafia, 2010. P. 83.

Інтернет-ресурси: http://www.plantarium.ru/page/view/item/10045.html

\title{
CHAMAEDAPHNE CALYCULATA (L.) MOENCH IN UKRAINE
}

\author{
S. L. Zhygalova*1, I. G. Olshanskyi ${ }^{1}$, O. A. Futorna ${ }^{2}$ \\ ${ }^{1}$ M.G. Kholodny Institute of Botany, NAS of Ukraine, 2, Tereshchenkivska St., Kyiv 01601, Ukraine \\ 2 O.V. Fomin Botanical Garden \\ Educational-Scientific Centre "Institute of Biology and Medicine" \\ National Taras Shevchenko University of Kyiv, 1, Symon Petlyura St., Kyiv 01601, Ukraine \\ *Corresponding author: e-mail: zhygalova2015@gmail.com
}

On the basis of critical processing of numerous literary sources and herbarium materials, information on a systematic position, morphological structure, ecological affiliation, geographical distribution and state of conservation of Chamaedaphne calyculata (L.) Moench are summarized. Chamaedaphne calyculata refers to the monotype genus Chamaedaphne from the family of heather (Ericaceae). Chamaedaphne calyculata - marsh and forest-marsh species of plants. In Ukraine, it is a glossy (Pleistocene) relic on the southern border of distribution, listed in the Red Data Book of Ukraine (2009), in a "vulnerable" status. Plant community dominated by C. calyculata are included in the Green Book of Ukraine (2009). Chamaedaphne calyculata has medicinal properties, as well as decorative, soil-protective, peatforming value. This species of plants is distributed in countries neighboring the Ukraine: Poland, Belarus, Russia. In the south of Belarus, it happens sporadically, and in Poland it is a rare plant species. In Ukraine, there are only a few C. calyculata localities. Using the SimpleMappr resource, we created a distribution map of this type. It has been determined that $C$. calyculata is protected in several objects of the nature reserve fund of Ukraine: Rivne and Polissya nature reserves, Vutvitsky, Svaricevitsky and Khinitsky botanical reserves of nationwide importance. According to the results of analysis of literary data, we came to a conclusion that this species requires the study of the current state of populations. Since most $C$. calyculata herbarium specimens were collected in the 50 s and 70 s of the last century, these localities require confirmation. It is also necessary to search for new localities of this species of plants. In view of the fact that not all C. calyculata habitats are protected we emphasize that, it is necessary to create new objects of the natural reserve fund of Ukraine or to expand the existing ones.

Keywords: Ericaceae, Chamaedaphne, Red Data Book of Ukraine

Одержано: 01.10.2018

ISSN 1996-4536 (print) • ISSN 2311-0783 (on-line) • Біологічні Студії / Studia Biologica • 2018 • Том 12/№3-4 • C. 95-102 